\title{
石炭単一粒子の高温ガス化反応における 溶融灰分の影響
}

\author{
(キーワード 石炭ガス化, 灰分溶融挙動, 高温石炭反応, 反応性)
}

-1991.8 .19 受理一

東京農工大学 林 石英, 二宮 善彦, 平戸 瑞穂

\section{1. 緒 言}

石炭のガス化反応性に関しては, 従来から石炭およ び石炭チャーの物理的, あるいは化学的因子に基づい た多くの研究が行われてきたが, これらの研究の多く

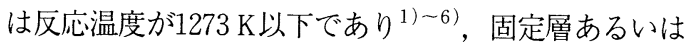
流動層ガス化炉を対象としてきた。一方，近年注目さ れる気流層高温ガス化炉は, 石炭灰分を溶融させつつ ガス化する方式で, 高温のためチャーのガス化速度は 大きく，化学反応律速下で進行するというよりむしろ 境膜拡散律速下で進行すると考えられており ${ }^{7) ~ 10) ， カ ゙ ~}$ ス化反応性に関する基礎的観点からの検討は必ずしも 多くはない。

牧野らは，灰分が溶融し始める温度域では灰分層の 拡散抵抗が大きいこと ${ }^{11)}$, 小山らは石炭灰の溶融温度 でチャー比表面積, 空隙率が低下すること ${ }^{12)}$ ，笠岡ら は灰分が溶融する温度域で反応速度が低下すること ${ }^{13)}$ などを報告している。これらの研究から，チャーの反 応性に及ほす溶融圧分の影響がある程度示唆されるが, チャー中の灰分がガス化過程でどのように溶融変化す るのか，その実態は明らかにされていない。また高温 域でのガス化では，石炭中に含まれる灰分が内部で軟 化溶融してチャーの細孔構造に変化を与え，しかも溶 融灰分と炭素質との固液反応の可能性も極めて高いと 考えられるが'14)，灰分の溶融過程をも考慮した反応解 析がほとんど行われていない。

本研究では，灰分が溶融する温度域における石炭 チャーの反応性ならびにチャー構造変化を検討するこ とを目的に，大粒径の石炭単一チャー粒子について粒

工学部 物質生物工学科

東京都小金井市中町 2-24-16
子断面上の炭素質ならびに灰分の構造変化を走査電子 顕微鏡（SEM）で観察し，チャー中の灰分の溶融に関 するガス化温度の影響を検討した。

\section{2. 実験装置および方法}

\section{1 実験装置}

本研究に用いた装置の概略を Fig. 1 に示す。実験装 置は高温電気炉 (カンタルスーパー発熱体), 排気室,

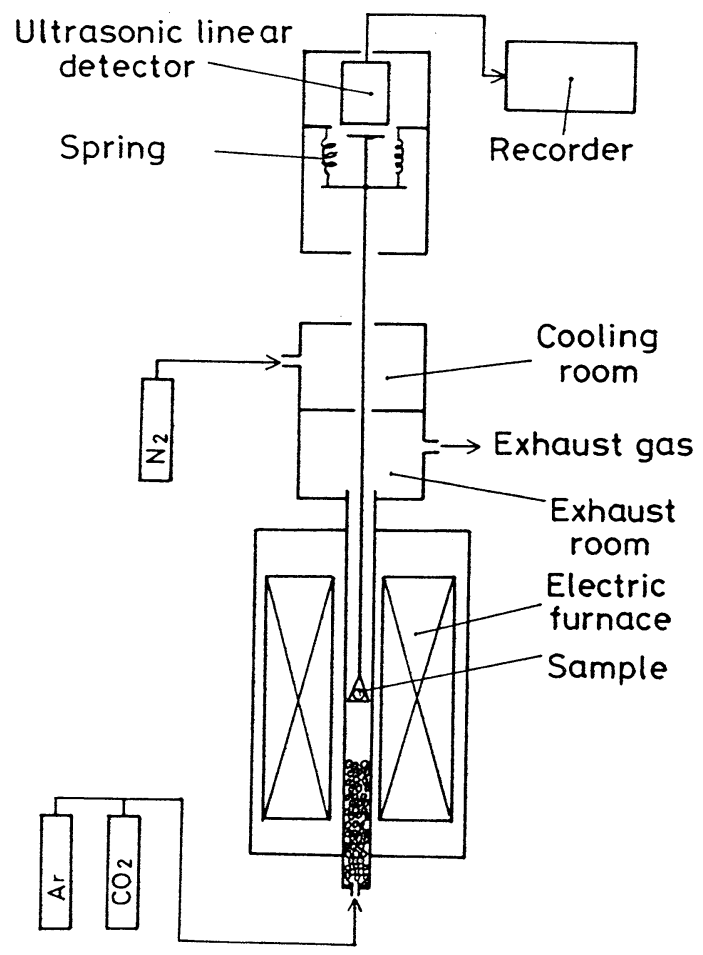

Fig. 1 Schematic diagram of experimental apparatus 
冷却室，天科部，ガス供給および計測システムから構 成されており，本装置は最高1923K までの実験が可能 となっている。反応管には高純度アルミナ管（内径 $35 \mathrm{~mm}$ ，長さ550mm）を使用し，下部にはガスの予熱部 を設けて供給ガスの予熱を行った。天科としては，今 回新たに大重量 $(0 \sim 5 \mathrm{~g})$ の重量変化に対して精度良 く測定できる熱天秤装置を試作した。基本的原理は, 試料の重量変化を 3 本の特殊バネの変位に置き換え, バネの変位を超音波センサー（スイス Baumer electric 社製）によって電気信号に変換して測定するもので, 0〜 $5 \mathrm{~g}$ の範囲にある試料について $0.01 \mathrm{~g}$ の精度で測 定が可能である。また，天科には上下移動機構が設け てあり，反応中の試料の降下，引き上げができるよう になっている。所定の反応率に達した試料は炉上部に 引き上げられ， $\mathrm{N}_{2}$ ガスで満たされた冷却室で反応を停 止できるようにした。

\section{2 実験方法}

本実験ではニューランズ炭を使用した。Table 1 には 工業分析, 元素分析，灰分組成および死分溶融温度を

Table 1 Properties of coal used in this work

\begin{tabular}{|c|c|}
\hline Proximate analysis & $($ dry wt $\%)$ \\
\hline Moisture & 2.3 \\
\hline Volatile matter & 37.4 \\
\hline Fixed carbon & 57.5 \\
\hline Ash & 2.8 \\
\hline Ultimate analysis & $($ dry wt $\%)$ \\
\hline Carbon & 73.5 \\
\hline Hydrogen & 4.8 \\
\hline Nitrogen & 1.6 \\
\hline Oxgen (by diff) & 17.3 \\
\hline Ash & 2.8 \\
\hline Ash chemical comp. & (wt \%) \\
\hline $\mathrm{SiO}_{2}$ & 42.75 \\
\hline $\mathrm{Al}_{2} \mathrm{O}_{3}$ & 29.64 \\
\hline $\mathrm{Fe}_{2} \mathrm{O}_{3}$ & 7.00 \\
\hline $\mathrm{CaO}$ & 8.12 \\
\hline $\mathrm{MgO}$ & 1.75 \\
\hline $\mathrm{Na}_{2} \mathrm{O}$ & 1.64 \\
\hline total & 90.90 \\
\hline Ash fusion temp. & (Reducing $\mathrm{K}$ ) \\
\hline Softening & 1763 \\
\hline Melting & $>1873$ \\
\hline Fluid & $>1873$ \\
\hline
\end{tabular}

示す。JIS M8801によって測定した溶融点は1873K 以 上であり，本実験範囲では石炭中の灰分の溶融はほと んどおきないことになるが，加熱ステージによる観察 の結果，還元䨌囲気下では1573K 付近から局所的な溶 融が認められた。この温度は軟化点より190K 低いこと になるが, $\mathrm{SiO}_{2}-\mathrm{Al}_{2} \mathrm{O}_{3}-\mathrm{CaO}$ 系の共晶点と概ね一致す る温度であった。

本実験では均一な組織の石炭塊（代表径約 $25 \mathrm{~mm}$ )を 選び出し, まず $\mathrm{N}_{2}$ 雲囲気下 $5 \mathrm{~K} / \mathrm{min}$ の昇温速度で, 1173K で30分間乾留した。冷却後, 亀裂や割れが生じ なかった部分を選び出し, 研磨により直径 $20 \mathrm{~mm}$ の球 に成形し実験試料にした。

ガス化温度は1273〜1773K まで100K 刻みとし， $\mathrm{Ar} / \mathrm{CO}_{2}$ 混合ガス $\left(\mathrm{CO}_{2}\right.$ 濃度 $\left.50 \%\right)$ を $1000 \mathrm{~cm}^{3} / \mathrm{min}$ 供給 した。実験は試料を白金ロジウム線で作ったバスケッ トにのせて天科に吊し，反応管中心部に降下させると ともに直後からの重量変化を連続測定した。所定のガ ス化率に達したときに試料を引き上げ，冷却室中で $\mathrm{N}_{2}$ ガスにより急速冷却して反応を停止させた。試料を切 断した後, 半径方向のチャーの構造変化を光学顕微鏡, SEM により観察した。

\section{3. 実験結果および考察}

\section{1 実験結果}

Fig. 2 に典型的なチャーの重量減少曲線を示す。こ こでガス化率 X は，チャー中の灰分を除いた炭素転化 率である。温度上昇にともないチャーのガス化速度は 大きくなるが, 初期反応速度に基づく粒子外表面積基 準の活性化エネルギーは $93 \mathrm{~kJ} / \mathrm{mol}$ であった。この值は, 宝田ら ${ }^{4)}$ が報告している活性化エネルギー（96 $297 \mathrm{~kJ} / \mathrm{mol}$ ）の中では低い部類に属している。一方, 反 応後期になると，灰相拡散を考慮した未反応壳モデ ル ${ }^{15)}$ で概ね整理でき，生成物の拡散層の影響が大きく

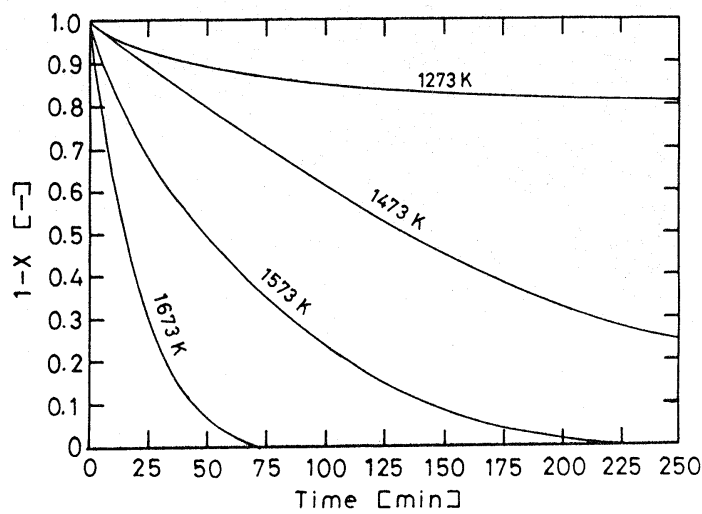

Fig. 2 Relation between conversion and time 


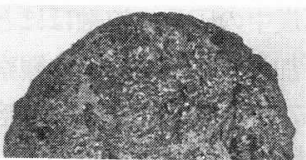

$x=0$
Azone Bzone Czone

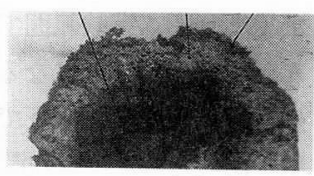

$x=0.2$
Azone Bzone Czone

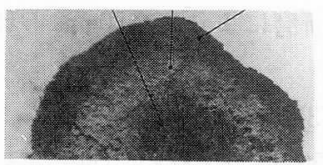

$x=0.7$

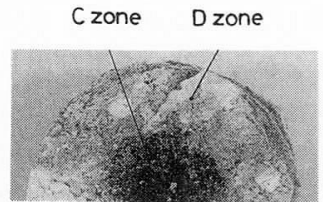

$x=0.95$
$10 \mathrm{~mm}$

Fig. 3 Sectional photograph of reacting char particle in $\mathrm{CO}_{2}$ gasification at $1573 \mathrm{~K}$

Table 2 Ash content in A, B, C and $D$ zones at $1573 \mathrm{~K}$

\begin{tabular}{cccc}
\hline \multicolumn{4}{c}{ Ash $($ dry wt\% $)$} \\
\cline { 2 - 4 } A zone & B zone & C zone & D zone \\
\hline 6.5 & 9.5 & 70.0 & 100.0 \\
\hline
\end{tabular}

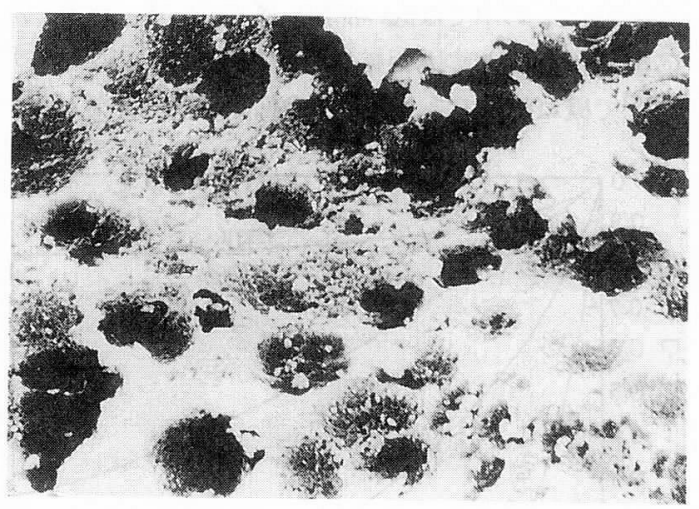

$10 \mu \mathrm{m}$

Fig. 4 SEM photograph of $B$ zone at $1573 \mathrm{~K}$ and $X=0.5$
なっていることがわかった。

粒子断面を光学顕微鏡で観察したところ，色調の違 いから同心円上に多層の反応層が現れた。一例として Fig. 3 には1573K の結果を示す。反応率70\%の粒子断 面上には 3 つの層が認められたが，反応が進行するに つれ， 2 層 $(X=0.95)$ に変化した。以後，中心の層 から順に $\mathrm{A}, \mathrm{B}, \mathrm{C}$ およびD層と呼び区別する。各層 の灰分の平均含有率を Table 2 に示す。この表から, $\mathrm{A}$ 層は未反応部分， $\mathrm{B}$ 層は主反応部分， $\mathrm{C}$ 層は少量の 炭素か残留した部分，D層は灰層であることがわかる。 Fig. 4 にはB 層のSEM 写真を示したが，B層のチャー 表面には直径抒拈よそ 5 10 $\mu \mathrm{m}$ の細孔が多数生成し, 反応の進行とともに細孔径の拡大はあまり認められず, その数のみが増加して細孔同士の合体がみられた。C 層は細孔の発達と合体過程が終了し, 炭素質が灰層間 に部分的に残存した状態である。

Fig. 5 には1273，1573および1673K の各温度におけ る, 各層の厚みの経時变化を示した。ガス化反応は主

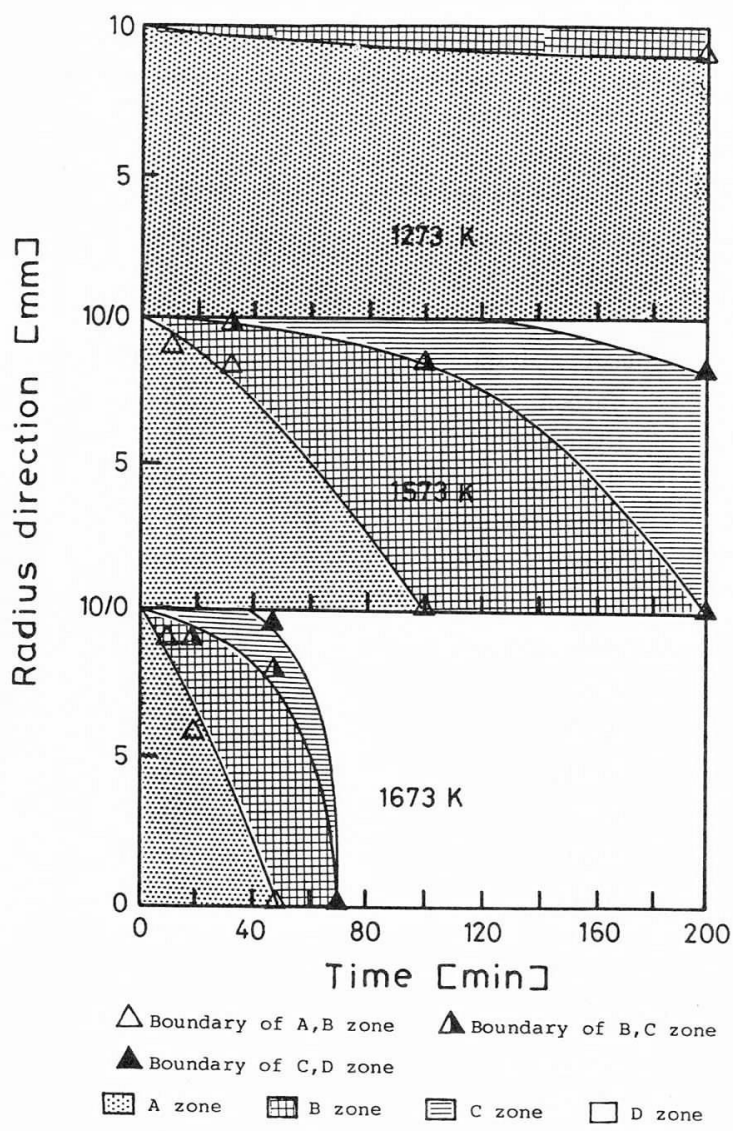

Fig. 5 Thickness of specified reaction zone 


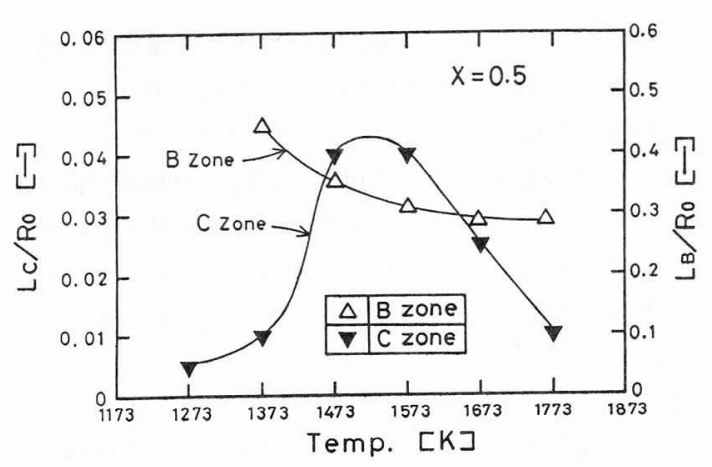

Fig. 6 Relation between dimensionless thickness of $\mathrm{B}, \mathrm{C}$ zone and temperature at $\mathrm{X}=0.5$ $\left(L_{B}\right.$ and $L_{C}$ are thicknese of $B$ and $C$ zone, respectively; $R_{0}$ is radius of particle)

Table 3 Rate constants of deashed chars at $1573 \mathrm{~K}$

\begin{tabular}{ccc}
\hline \multicolumn{3}{c}{$\mathrm{Ks}\left(\mathrm{kg} \cdot \mathrm{Pa}^{-1} \cdot \mathrm{m}^{-2} \cdot \mathrm{s}^{-1}\right)$} \\
\hline A zone & B zone & C zone \\
$4.15 \times 10^{-8}$ & $3.94 \times 10^{-8}$ & $3.65 \times 10^{-8}$ \\
\hline
\end{tabular}

にB 層で進行し，A層消滅時にはB 層の約 8 割程度が 反応層として残り, 正確には未反応殼モデルで記述で きないことが明らかになった。1473〜1573 K の温度範 囲では，B層消滅時においても約 7 ～割程度のC 層 が残り，C層の反応性の低さが顕著である。比較のた め反応率 $50 \%$ 時の B，C層の厚みを Fig. 6 に示寸が, B 層は温度とともにチャーのガス化速度が大きくなる ため薄くなる傾向がみられる。一方、C 層は1473〜 1573K の温度範囲で最も厚く, これ以外の温度域では 逆に薄くなっている。C層はB層より外側にあるため, ガス境膜, 灰層内拡散の影響は小さいはずであるが, この温度域では見かけのガス化速度は小さくなること がみいだされた。

各層に含まれる炭素質の反応性を検討するため, 1573K のチャー（A，BおよびC 層）を脱兏した炭素 質の $\mathrm{CO}_{2}$ ガス化速度（1573K）を TG を用いて測定した。 これらの結果を Table 3 に示す。表から A， B および C 層の反応速度はほぼ一致し, C 層に残留した炭素質 の反応性が特に劣っていないことがわかった。

3.2 ガス化反応性に及ぼす溶融灰分の影響

高温下における単一粒子のガス化反応は，理想的な 末反応殼モデルや連続反応モデルではなく, 反応域モ デルで進行し, 反応带の色調の違い及び扊分含有量か ら反応は 2 層に分かれて進行していることを確認した。
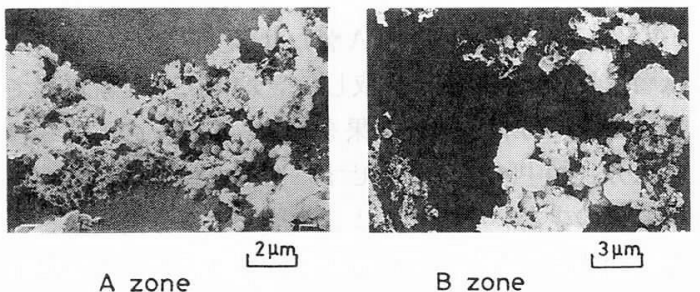

A zone
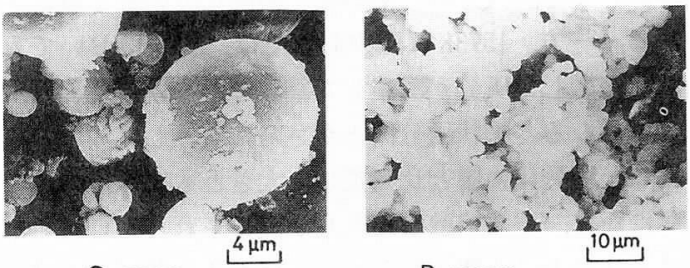

C zone

D zone

(c) $1673 \times$

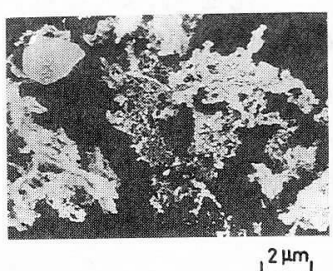

A zone

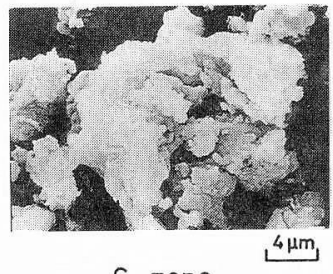

C zone

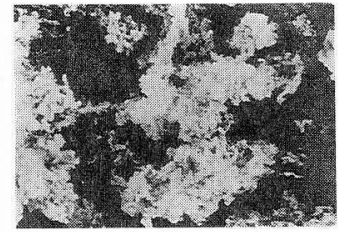

$2 \mu \mathrm{m}$

A zone

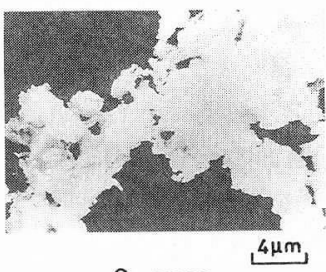

C zone

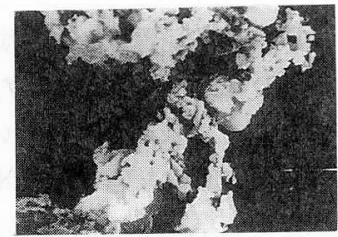

$3 \mu \mathrm{m}$

B zone

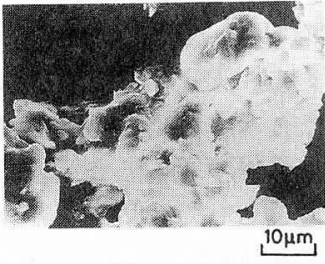

D zone

$1573 \mathrm{~K}$

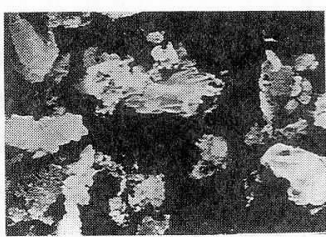

B zone

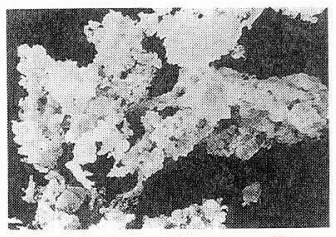

D zone
Fig. 7 Behavior of ash melting in char

( $A, B$ zones at $X=0.3$ and $C, D$ zones at $X=0.8)$ 
Fig. 7 には，未反応層（A層），反応層（B， C 層）, 灰層（D層）の一部を採取し，空気中 $815^{\circ} \mathrm{C} て ゙$ 加熱して 灰化した扊分相の観察結果を示す。1273K のA，B層 の灰分（図中(a)）は溶融せずに原型を保っているが, 炭素分の少ないC 層, およびD層では灰分同士が疑集 して網状につながっているのか観察された。この温度 に扔いても，灰分の一部は軟化溶融していると推定さ れる。一方，1573K（図中(b)）では，A層においても 軟化溶融した灰分が凝集して網状につながっており， B 層になると網状灰分同士がさらに凝集していた。凝 集した死分は $\mathrm{A}$ 層と比へ長さ, 太さともに数倍の集合 体になり，一部溶融した扊分か観察された。C層では 集合体同士の合体が抗こり，一部大きな球形に溶融合 体した灰分がみられた。なお，灰化処理により凝集し た灰分が多孔質になり，炭素分の取り込みが観察され た。D層になると凝集した扊分同士が鎖がり，網状の 灰分が粒子表面を覆っている。1673K（図中(c)) にな ると，A層においても局部的に溶融した小さい球状の 灰分が観察され， $\mathrm{B}$ 層では網状の灰分も多少認められ たが，大部分の灰分は溶融していた。C層になるとほ とんどの灰分が溶融して球形粒子になり，D層では平 均 $5 \mu \mathrm{m}$ 程度の球形粒子が鎖がり, 粒子表面を覆って いた。灰分の状態としては，1573K の場合と比べ溶融 が進み，大部分の灰分は球形に変化していた。

C 層のガス化速度が1473 1573K の範囲で低下する 原因としては，この温度域では溶融灰分の粘度が高く 流動性が悪いため, 一種の高粘度スラリー状態となり, 凝集灰分の内部に炭素質が取り込まれるためと考えら れる。一方，1273K 以下では，チャー中の灰分の溶融 がほとんどおこらないために，極端な反応性の低下が みられなかったと考えられる。1673K 以上の場合には, 灰分はほぼ溶融し，チャーに対する溶融灰分の濡れ性 は悪く，溶融した灰分はチャー表面を覆わず球形に変 化するため反応性は維持され，また，溶融灰分と炭素 との接触面で固液反応が進行して, 反応が逆に促進さ れるものと考えられる。

\section{4. 結 言}

高温領域におけるニューランズ炭単一チャー粒子の $\mathrm{CO}_{2}$ ガス化実験を行い, 粒子断面のチャーの構造, 灰 分の状態を観察し, 以下の結果を得た。

（1）粒子断面を光学顕微鏡で観察したところ, 反応
中の単一粒子は, 色調および含有灰分量の違いか ら同心円的に 2 層の反応層に分かれ，ガス化反応 は主にB層で進行していることがわかった。

（2） C層のガス化速度は1473～1573K の範囲で低下 した。この理由はこの温度域の溶融灰分の粘度が 高く流動性が悪いため, 一種の高粘度スラリーに なり, 凝集灰分の内部に炭素質が取り込まれるた めと考えられる。

（3） 1673K 以上のガス化温度では，未反応層におい ても局部的に溶融した小さい球状の灰分が観察さ れた。

\section{文献}

1) Dutta S. and Wen, C. Y., Ind. Eng, Chem. Process Des. Dev., 16, 1, 20 (1977)

2) 橋本健治, 三浦孝一, 燃協誌, 65, 10, 798 (1986)

3) 武田詔平, 本間専治, 田崎米四郎, 弓山 翠, 北 野邦尋, 河端淳一, 千葉忠俊, 竹沢暢恒, 燃協誌, 67, 9, 764 (1988)

4）宝田恭之, 井田直幸, 日置明夫, 神原信志, 山本 美奈子，加藤邦夫，燃協誌，67，12，1061（1988）

5) Goyal, A., Zabransky R. F. and Rehmat, A., Ind. Eng. Chem. Res., 28, 1767 (1989)

6) Foster M. D. and Jensen, K. F., Fuel, 69, 1, 88 (1990)

7) Wicke,E., Chem. Ing. Tech., 29, 305 (1957)

8) Wen C. Y. and Chaung, T. Z., Ind. Eng. Chem. Process Des. Dev., 18, 4, 684 (1979)

9) Govind R. and Shah, J., AIChE J., 30, 1, 79 (1984)

10）林 石英, 亀山修二, 二宮善彦, 平戸瑞穂, 燃協 誌，69，3，191 (1990)

11）牧野三則, 海保 守, 小林光雄, 山田 理, 山下 安正, サンシャインジャーナル， 7, 28 (1986)

12）小山俊太郎, 松尾光広, 宮寺 博, 燃協誌， 65, 8, 660 (1986)

13）笠岡成光，阪田祐作，童 楚良，燃協誌， $62 ， 673$, 335 (1983)

14）西 徹, 原口 博，奥原捷晃，燃協誌， 69,2 , 126 (1990)

15) Levenspiel, O., 'Chemical reaction engineering', Second Ed., John Wiley \& Sons, p. 366 (1972) 


\title{
Effect of Ash Melting on the High Temprature Gasification of a Single Large Particle of Coal Char
}

\author{
Shiying Lin, Yoshihiko NinOMIYA and Mitsuho HIRATO \\ (Tokyo University of Agriculture and Technology)
}

\begin{abstract}
SYNOPSIS : - A single particle of coal char was gasified with $\mathrm{CO}_{2} / \mathrm{Ar}$ atmosphere at the temperature of 1273 to $1773 \mathrm{~K}$. The pore structure and the ash properties in a gasified char particle were investigated.

Two kinds of reacting zone(B, $\mathrm{C}$ zone) were observed in the char. Primary gasification occurred in inner shell (B zone) and the thickness of the shell decreased with temperature. The thickness of $\mathrm{C}$ zone which consists of ash and unreactive residue (carbon content is below $30 \mathrm{wt} \%$ ) maximized at the temprature range of 1473 to $1573 \mathrm{~K}$. This suggests that the residue is surrounded by cohered ash or high viscous melting ash and that gasification reaction is prevented. Above $1673 \mathrm{~K}$, ash was completely melted and the thicknese of $\mathrm{C}$ zone, therefore, decreased. Small sphere ash particles were observed within unreactive char.
\end{abstract}

\section{Key Words}

Coal gasification, Melting behavior of ash, High temperature coal reaction, Reactivity

IIIIIIIIIIIIIIIIIIIIIII

書 評

IIIIIIIIIIIIIIIIIIIII!I

\section{新版 熱計算入門}

\author{
I 大屋正明著 熱力学の基礎 \\ II 竹内正雄著 伝熱・流体の流れ \\ III 山崎正和著 燃焼計算 \\ 省エネルギーセンター刊（各巻定価1,900円）
}

エネルギー資源問題, 環境問題で燃料の有効利用や省エネルギーの推進が要請され, 熱利用設備管理運営の適正化が問題 になって，エネルギー管理士（熱管理）国家試験の重要な課目になっていることはご承知のとおりです。

本書はこれらの事情を背景に, 熱力学の基礎, 伝熱・流体の流れ, 燃焼計算, の三分冊として刊行されたもので, エネル ギー管理士国家試験用参考書として最適の高著である。理論展開や解析より，現実の設備に関する熱計算に主力がおかれて いるので内容は平明簡潔であり, 多くの計算例や解答付の問題が併載されており, 受験用ばかりでなく現場設備の理解にも 役立つ有用な参考書である。

エネルギー管理士試験の受験者のみでなく, 現地作業者, 熱関係の仕事に携る技術者や学生にも是非扔推めしたい。 